\title{
CHANGES IN CHLOROPHYLL CONTENT AND FLUORESCENCE AND FRUIT YIELD CONTRIBUTING TRAITS IN DIFFERENT GENOTYPES OF STRAWBERRY (Fragaria $\mathrm{x}$ ananassa DUCH.)
}

\author{
Elżbieta Kaczmarska ${ }^{1}$, Władysław Michałek ${ }^{2}$ \\ ${ }^{1}$ Department of Genetics and Plant Breeding, ${ }^{2}$ Department of General Ecology, University of Life Sciences in Lublin \\ Akademicka 15, 20-950 Lublin, Poland \\ e-mail: elzbieta.kaczmarska@up.lublin.pl
}

Received: 28.02.2013

\begin{abstract}
Analysis of changes in chlorophyll fluorescence parameters in strawberry leaves was based on a field experiment performed in the years 2009-2010. Ten genotypes including 5 cultivars: 'Kent', 'Teresa', 'Senga Sengana', 'Chandler' and the breeding clone 1387 as well as their inbred progeny, were the object of the study. During the experiment the following indicators were evaluated: chlorophyll $\mathrm{a}$ and $\mathrm{b}$ content in fresh leaf mass as well as fluorescence parameters: minimum $\left(\mathrm{F}_{0}\right)$ and maximum fluorescence yield $\left(\mathrm{F}_{\mathrm{m}}\right)$, photochemical efficiency of PS II $\left(\mathrm{F}_{\mathrm{v}} / \mathrm{F}_{\mathrm{m}}\right)$, actual quantum yield of PSII photochemistry (Y), minimum $\left(\mathrm{F}_{0}{ }^{\prime}\right)$ and maximum efficiency of fluorescence $\left(\mathrm{F}_{\mathrm{m}}{ }^{\prime}\right)$ in the light, coefficient of photochemical (qP) and non-photochemical (qN) fluorescence quenching. In this work, we also examined the effect of repeated inbreeding on strawberry fruit yield and yield components. The analysis of changes of these parameters showed that inbreeding caused a reaction in all tested cultivars. In all inbred progeny, chlorophyll a and b content decreased compared to the cultivars. Generally, the photochemical efficiency of photosystem II $\left(\mathrm{F}_{\mathrm{v}} / \mathrm{F}_{\mathrm{m}}\right)$ and the parameter $\Delta \mathrm{F} / \mathrm{F}_{\mathrm{m}}$, were not affected by strong inbreeding. In analyzing the values of the coefficients $\mathrm{qP}$ and $\mathrm{qN}$, it has been observed that changes in their values depend on the sensitivity of the examined genotypes to self-pollination. The functioning of PS II is the most sensitive indicator of the effect of various factors on plants and is useful, among others, in breeding to select plants with a required genotype.

The yield - determining features such as: fruit yield per plant, weight of single fruit, number of fruit per plant and weight of leaves per plant in $\mathrm{S}_{3}$ generation, were lower as compared with parental forms.
\end{abstract}

Key words: Fragaria $x$ ananassa Duch., cultivars, photosynthetic activity, chlorophyll a and b, inbreeding depression

\section{INTRODUCTION}

Photosynthesis is a basic physiological process of plants with external and internal conditions. Measurement of chlorophyll fluorescence largely replaces the conventional measurements of the rate of photosynthesis and is a highly sensitive plant photosynthetic reaction attempt [1,2]. Chlorophyll fluorescence measurements are completely non-invasive, allowing photosynthesis to be studied in vivo. This method is particularly useful when the effects of different environmental factors $[3,4,5,6]$, and biotic stress $[7,8]$ on plants are studied.

Inbreeding generally increases homozygosity in plants and more homozygous genotypes may be susceptible to environmental harshness. In contrast, outcrossing usually increases or maintains heterozygosity that tends to produce genotypes better able to buffer themselves against environmental variability [9]. Inbreeding depression, the reduction in fitness of progeny derived from inbreeding relative to those derived from outcrossing, is invoked to explain the maintenance of the plant mating system [10].

Fragaria $\mathrm{x}$ ananassa $(2 \mathrm{n}=8 \mathrm{x}=56)$, the cultivated strawberry, is a hybrid produced from a cross between the two New World octoploid strawberry species, $F$. chiloensis and $F$. virginiana, and is grown for its economically important fruit throughout the temperate regions of the world. Currently, there are over 100 breeding programmes worldwide, aiming to develop superior cultivars with improved flavour and texture, extended seasons of harvest, and a longer post-harvest shelf-life [11]. Experiments with strawberry have demonstrated significant and occasionally severe trait 
mean depression for populations of inbred offspring constructed from matings among current-generation; fruit yields were depressed significantly even when rather modest rates of inbreeding were applied [12].

On the other hand, the level of genetic diversity in germplasm is a critical point of new cultivar creation, because inbreeding in cultivated plants leads to rapid loss in vigour, yield and fruit size [13].

We aimed to find a relationship between inbreeding depression and changes in the chlorophyll content and fluorescence. The presented research is innovative because of the lack of data in the literature on these subjects.

The aim of this study was to compare chosen photosynthetic parameters in the leaves of five strawberry cultivars and their inbred counterparts - third generation self $\left(\mathrm{S}_{3}\right)$. The study also evaluated the effect of inbreeding on yield, vigor and yield contributing characters in strawberry.

\section{MATERIALS AND METHODS}

The experiments testing the strawberry germplasm were conducted in the period 2009-2010 at the Felin Research Plantation of the University of Life Sciences in Lublin. Four strawberry cultivars: 'Senga Sengana' ('Sieger' x 'Markee'), 'Kent' (('Redgauntlet' x 'Tioga') x 'Raritan'), 'Teresa' ('Redgauntlet $\mathrm{S}_{1}$ ' x 'Senga Sengana'), 'Chandler' ('Douglas' x Cal 85.218-605), the breeding clone 1387 (('Redgauntlet $S_{1}$ ' x 'Senga Sengana $S_{1}{ }^{\prime}$ ) x 'Tioga $S_{1}$ ) and third generation inbreds derived from them were examined.

The first self-pollination was performed in May 2004. Before flowering time, inflorescences were covered with small bags made of cloth and left undisturbed for spontaneous selfing. 150 seedlings $\left(S_{1}\right)$ derived from each of the cultivars (non-inbred progenies) were used in field trials on September 10, 2005. In May 2006, the second self-pollination was performed. Twenty seedlings randomly chosen from the first-generation self were self-pollinated to generate the second-generation self $\left(\mathrm{S}_{2}\right)$. Afterwards, 10 seedlings were retained from this population and used as parents to obtain the third-generation self $\left(S_{3}\right)$. In June 2009 , 10 seedlings derived from the same $S_{2}$ parental plants were planted on a separate experimental plot. Thus, the generation $\mathrm{S}_{3}$ consisted of 100 plants of each cultivar (a total of $500 \mathrm{~S}_{3}$ plants were examined).

Field measurements of the chlorophyll fluorescence parameters were performed using a fluorometer PAM-2000 by Walz GmbH, Germany. Chlorophyll fluorescence was measured on randomly selected, fully expanded triplet leaves that were in a similar physiological condition. The leaves were subjected to dark treatment for $20 \mathrm{~min}$ [14]. The measurements were made in triplicate on the designated plants of each cultivar and inbred progeny on September 24, 2009, and September 20, 2010.

Over the study period, the following indices were recorded:

- chlorophyll a and b content in fresh leaf mass;

- $\mathrm{F}_{0}$ - minimum efficiency of fluorescence;

- $\mathrm{F}_{\mathrm{m}}$ - maximal fluorescence yield after dark adaptation;

- $F_{v} / F_{m}$ - photochemical efficiency at PS II [15];

- Y - actual quantum yield of PSII photochemistry;

- $\mathrm{F}_{0},-$ minimum efficiency of fluorescence in the light;

- $F_{m}$ - maximum efficiency of fluorescence in the light;

- $\mathrm{qP}$ - coefficient of photochemical fluorescence quenching;

- $\mathrm{qN}$-coefficient of non-photochemical fluorescence quenching.

Chlorophyll $\mathrm{a}$ and $\mathrm{b}$ content in fresh leaf mass was determined by the spectrophotometric method described by Lichtenthaler and Wellburn [16].

During the research we also estimated: fruit yield per plant, fruit number per plant, average fruit weight, weight of leaves per plant. Data for growth and productivity traits were collected for individual plants (non-inbred cultivars and inbreeding populations) throughout the season following the plantation establishment. Weight of leaves per plant was obtained on July 20, after harvest. Yields and fruit number were recorded for each plant for 4 consecutive weeks starting from the first week of June. The weight of a single fruit was calculated by dividing weekly yields by corresponding fruit numbers. The results given are the average for two years of the research.

Variance analysis of the results obtained from the analyses and measurements was performed using Tukey's test, defined in this work as $\mathrm{LSD}_{0.05}$.

\section{RESULTS}

The functioning of photosystem II is the most sensitive indicator of various stress factors on plants. Changes in PS II activity can be determined quickly and non-invasively by measuring chlorophyll fluorescence (FC). The results obtained from FC induction measurements allow us to assess the progress and performance of photochemical reactions of light-phase photosynthesis leading to the formation of the so-called 'assimilation power' and its relationship to enzymatic reactions of photosynthesis. This in turn allows 
us to determine the physiological state of plants growing in unfavorable environmental conditions.

In 2009 and 2010, the highest chlorophyll a content was found in the cultivar 'Chandler' $(1.32 \mathrm{mg} \times$ $\left.\mathrm{g}^{-1}\right)$, whereas the highest level of chlorophyll $\mathrm{b}$ was observed in 'Kent' and the clone $1387\left(0.40 \mathrm{mg} \times \mathrm{g}^{-1}\right)$. As shown in Table 1, there was a decrease in chlorophyll a (by an average of 10\%) and chlorophyll b content (by $18 \%)$ in all inbred progeny. Due to this fact, the ratio of chlorophyll $\mathrm{a} / \mathrm{b}$ content in inbred progeny averaged 3.66 as compared to the cultivars -3.33 .

Table 2 presents the changes in the chlorophyll fluorescence parameters in the leaves of the cultivars and their inbred progeny under field conditions. The minimum efficiency of fluorescence $\left(\mathrm{F}_{0}\right)$ showed a considerable variability, depending on clone, and ranged from $0.108\left(1387 \mathrm{~S}_{3}\right)$ to 0.249 ('Teresa' $\mathrm{S}_{3}$ ).

In our study, a decrease in maximum efficiency of fluorescence $\left(\mathrm{F}_{\mathrm{m}}\right)$ was observed in all inbred progeny, on average by $19 \%$ compared to the cultivars, which indicates the photoinhibition changes in the strawberry leaves.

The maximum effect of photosystem II measured on dark-adapted strawberry leaves $\left(\mathrm{F}_{\mathrm{v}} / \mathrm{F}_{\mathrm{m}}\right)$ was higher in the $\mathrm{S}_{3}$ progeny by an average of $2 \%$ compared to the cultivars and the highest increase (by 13\%) was observed in the 'Chandler' cultivar. The data presented in Table 3 indicate that, among the studied genotypes, inbred progenies of 'Chandler' were distinguished by another reaction to selfing - there was an increase in fruit yield in $\mathrm{S}_{3}$ and in number of fruits per plant.

The average value of the $\mathrm{Y}$ parameter in the $\mathrm{S}_{3}$ progeny increased by $18 \%$ compared to the cultivars. In all offspring, with the exception of 'Kent' $S_{3}$, an increase in this parameter was observed.

The results indicate that in all of the offspring (with the exception of the clone $1387 \mathrm{~S}_{3}$ ) there was an increase in minimum efficiency of fluorescence in the light $\left(\mathrm{F}_{0}{ }^{\prime}\right)$ which is expressed by an average increase of $17 \%$. In 2009 and 2010 the clone 1387 and the progeny 'Teresa' $S_{3}$ had the highest maximum efficiency of fluorescence in the light $\left(\mathrm{F}_{\mathrm{m}}\right.$ ' parameter $=0.410$ and 0.361 , respectively) of all 10 genotypes.

The highest and most favorable values of the photochemical fluorescence quenching coefficient (qP) were also found in 'Teresa' and therefore it is the least sensitive cultivar. In the present study, this strawberry cultivar was characterized by the most favorable ratio of the number of photons absorbed by PSII to the number of photons used by open centers in the reactions of photosynthesis. The value of the qN parameter decreased in all offspring, except for 'Chandler' $\mathrm{S}_{3}$ plants.

As shown in Table 3, strong inbreeding caused a decrease in the value of all studied traits: fruit yield per plant decreased by $23 \%$, weight of single fruit by $31 \%$, number of fruit per plant by $48 \%$, and weight of leaves per plant was reduced by as much as $67 \%$.

Table 1

Chlorophyll content in strawberry leaves (average results for 2009-2010)

\begin{tabular}{lccc}
\hline & \multicolumn{2}{c}{ Chlorophyll content in $\mathrm{mg} \times \mathrm{g}^{-1}$ fresh mass } \\
\cline { 2 - 4 } Cultivar $\left(\mathrm{S}_{0}\right) /$ Inbred progeny $\left(\mathrm{S}_{3}\right)$ & chlorophyll a & chlorophyll b & chlorophyll a/b \\
\hline Senga Sengana $\left(\mathrm{S}_{0}\right)$ & 1.182 & 0.341 & 3.47 \\
$1387\left(\mathrm{~S}_{0}\right)$ & 1.262 & 0.400 & 3.16 \\
Teresa $\left(\mathrm{S}_{0}\right)$ & 1.205 & 0.332 & 3.63 \\
Kent $\left(\mathrm{S}_{0}\right)$ & 1.232 & 0.401 & 3.07 \\
Chandler $\left(\mathrm{S}_{0}\right)$ & 1.320 & 0.398 & 3.32 \\
Mean & 1.240 & 0.374 & 3.33 \\
LSD & 0.05 & 0.034 & 0.12 \\
Senga Sengana $\left(\mathrm{S}_{3}\right)$ & 1.121 & 0.293 & 3.82 \\
$1387\left(\mathrm{~S}_{3}\right)$ & 1.082 & 0.299 & 3.62 \\
Teresa $\left(\mathrm{S}_{3}\right)$ & 1.093 & 0.301 & 3.63 \\
Kent $\left(\mathrm{S}_{3}\right)$ & 1.112 & 0.315 & 3.53 \\
Chandler $\left(\mathrm{S}_{3}\right)$ & 1.170 & 0.317 & 3.69 \\
Mean & 1.116 & 0.305 & 3.66 \\
LSD & 0.084 & 0.016 & 0.14 \\
\hline
\end{tabular}


Table 2

Development of changes in chlorophyll fluorescence parameters in strawberry (average results for 2009-2010)

\begin{tabular}{|c|c|c|c|c|c|c|c|c|}
\hline \multirow{2}{*}{ Cultivar $\left(\mathrm{S}_{0}\right) /$ Inbred progeny $\left(\mathrm{S}_{3}\right)$} & \multicolumn{8}{|c|}{ Chlorophyll fluorescence parameters } \\
\hline & $\mathrm{F}_{0}$ & $F_{m}$ & $\mathrm{~F}_{\mathrm{v}} / \mathrm{F}_{\mathrm{m}}$ & $\mathrm{Y}$ & $\mathrm{F}_{\mathrm{o}}$ & $\mathrm{F}_{\mathrm{m}}$ & $\mathrm{qP}$ & $\mathrm{qN}$ \\
\hline Senga Sengana $\left(\mathrm{S}_{0}\right)$ & 0.187 & 0.767 & 0.756 & 0.249 & 0.118 & 0.317 & 0.647 & 0.217 \\
\hline $1387\left(\mathrm{~S}_{0}\right)$ & 0.213 & 0.810 & 0.737 & 0.425 & 0.194 & 0.410 & 0.435 & 0.262 \\
\hline Teresa $\left(\mathrm{S}_{0}\right)$ & 0.198 & 0.867 & 0.772 & 0.406 & 0.173 & 0.343 & 0.672 & 0.221 \\
\hline Kent $\left(\mathrm{S}_{0}\right)$ & 0.197 & 0.823 & 0.761 & 0.462 & 0.120 & 0.339 & 0.572 & 0.190 \\
\hline Chandler $\left(\mathrm{S}_{0}\right)$ & 0.223 & 0.725 & 0.692 & 0.325 & 0.098 & 0.278 & 0.501 & 0.078 \\
\hline Mean & 0.204 & 0.798 & 0.744 & 0.373 & 0.141 & 0.317 & 0.565 & 0.195 \\
\hline $\operatorname{LSD}_{0.05}$ & 0.017 & 0.033 & 0.029 & 0.051 & 0.027 & 0.041 & 0.036 & 0.019 \\
\hline Senga Sengana $\left(\mathrm{S}_{3}\right)$ & 0.145 & 0.609 & 0.762 & 0.512 & 0.202 & 0.340 & 0.495 & 0.148 \\
\hline $1387\left(\mathrm{~S}_{3}\right)$ & 0.108 & 0.530 & 0.796 & 0.439 & 0.145 & 0.207 & 0.520 & 0.143 \\
\hline Teresa $\left(\mathrm{S}_{3}\right)$ & 0.249 & 0.818 & 0.696 & 0.560 & 0.202 & 0.361 & 0.534 & 0.100 \\
\hline Kent $\left(\mathrm{S}_{3}\right)$ & 0.159 & 0.641 & 0.752 & 0.354 & 0.153 & 0.207 & 0.465 & 0.177 \\
\hline Chandler $\left(\mathrm{S}_{3}\right)$ & 0.131 & 0.636 & 0.794 & 0.414 & 0.149 & 0.243 & 0.433 & 0.125 \\
\hline Mean & 0.158 & 0.647 & 0.756 & 0.456 & 0.170 & 0.272 & 0.489 & 0.139 \\
\hline $\mathrm{LSD}_{0.05}$ & 0.023 & 0.069 & 0.047 & 0.027 & 0.030 & 0.044 & 0.033 & 0.021 \\
\hline
\end{tabular}

Table 3

Characteristics of strawberry cultivars and $\mathrm{S}_{3}$ progeny in terms of yield and weight of leaves per plant (average results for 2009-2010)

\begin{tabular}{|c|c|c|c|c|}
\hline Cultivar $\left(\mathrm{S}_{0}\right) /$ Inbred progeny $\left(\mathrm{S}_{3}\right)$ & $\begin{array}{c}\text { Fruit yield } \\
\text { per plant }(g)\end{array}$ & $\begin{array}{l}\text { Number of fruit } \\
\text { per plant }\end{array}$ & $\begin{array}{l}\text { Weight of fruit } \\
(\mathrm{g})\end{array}$ & $\begin{array}{c}\text { Weight of leaves } \\
\text { per plant }(\mathrm{g})\end{array}$ \\
\hline Senga Sengana $\left(S_{0}\right)$ & 139.87 & 42.66 & 6.17 & 106.87 \\
\hline $1387\left(\mathrm{~S}_{0}\right)$ & 152.69 & 44.12 & 8.89 & 133.33 \\
\hline Teresa $\left(\mathrm{S}_{0}\right)$ & 197.20 & 51.30 & 9.02 & 172.50 \\
\hline $\operatorname{Kent}\left(\mathrm{S}_{0}\right)$ & 128.17 & 46.53 & 8.07 & 75.00 \\
\hline Chandler $\left(\mathrm{S}_{0}\right)$ & 117.00 & 33.50 & 5.12 & 88.33 \\
\hline Mean & 146.99 & 43.62 & 7.45 & 115.21 \\
\hline $\mathrm{LSD}_{0.05}$ & 35.76 & 7.75 & 2.33 & 55.98 \\
\hline Senga Sengana $\left(\mathrm{S}_{3}\right)$ & 72.32 & 14.23 & 5.07 & 34.01 \\
\hline $1387\left(\mathrm{~S}_{3}\right)$ & 127.80 & 20.11 & 4.87 & 33.56 \\
\hline Teresa $\left(S_{3}\right)$ & 104.00 & 18.41 & 5.88 & 41.71 \\
\hline Kent $\left(\mathrm{S}_{3}\right)$ & 118.44 & 24.53 & 4.71 & 38.24 \\
\hline Chandler $\left(\mathrm{S}_{3}\right)$ & 139.46 & 34.34 & 4.53 & 36.02 \\
\hline Mean & 113.68 & 22.85 & 5.17 & 37.87 \\
\hline $\mathrm{LSD}_{0.05}$ & 18.29 & 8.69 & 2.14 & 5.64 \\
\hline
\end{tabular}

\section{DISCUSSION}

The genetic characteristics of the tested cultivars most differentiated the photosynthetic performance indicators in strawberry plants (Tables 1 and 2). Michałek and Sawicka [17] reported that the content of chlorophyll $a$ and $b$ in fresh mass of potato leaves depended on the cultivar and growth stage of plants. The highest chlorophyll a content was found at full bloom, while that of chlorophyll b during emergence.

The $F_{v} / F_{m}$ ratio in control plants is usually $0.80-0.83$ and is a measure of potential quantum yield of photosystem PS II [18]. In the present work, the average values of potential quantum efficiency PS II (the parameter $\mathrm{F}_{\mathrm{v}} / \mathrm{F}_{\mathrm{m}}$ ) were similar in the leaves of inbred 
and non-inbred plants. Similarly, R a z a vi et al. [6] demonstrated in strawberry that maximum efficiency of photosystem II was not affected by drought stress.

As a result of using the fluorescence method, a decrease in the efficiency of photosynthesis after stress caused by aphids feeding was found in the leaves of all the tested hazel cultivars $[19,20,8]$.

A study by Cichocka et al. [21] showed a slower rate of photosynthesis after a few weeks of preying by various species of aphids on all the studied host plants. A strong reaction of the photosystem to preying aphids was especially well visible in different species of trees and shrubs. For example, photosynthesis in hawthorn leaves injured by Dysaphis crataegi decreased 4-5 times as compared to the control [22].

In certain conditions, however, plants - due to induced defence - tolerate the presence of pests. The authors explain this phenomenon by growth stimulation, an increase in photosynthetic rate, a change in the distribution of assimilative substances or fast necrotization of tissues. In this way, they are capable of compensating the losses, which balances the negative effect of some biotic stress, thanks to which plants remain in a good condition and they yield well [23].

A study by Gantner and Michałek [8] showed that the ability to convert PAR photon energy to chemical energy in light conditions decreased in the leaves of all the tested hazel cultivars. The $\Delta \mathrm{F} / \mathrm{F}_{\mathrm{m}}$, parameter was reduced on average by $27 \%$ after aphid feeding in comparison with the control.

On the other hand, poor infection of bean, strawberry, chrysanthemum and cucumber plants by red spiders caused an increased rate of photosynthesis, which contributed to increased metabolism and induction of a defensive reaction, leading as a consequence to losses and even growth stimulation and improved yielding [24].

The results from our study confirmed the data found in the literature concerning the great variability of non-photochemical chlorophyll fluorescence quenching (qN). According to $\mathrm{S} \mathrm{aw} \mathrm{icka} \mathrm{and} \mathrm{Mich}$ ałe k [25], this coefficient in sunflower plants was the least stable and ranged from 0.092 to 0.356 , depending on variety. K rebs et al. [26] also considered that indicator as not very stable.

In the study by $\mathrm{R}$ azavi et al. [6], the effect of water deficit on chlorophyll fluorescence, sugar content, and growth parameters of strawberry was investigated. A gradual reduction of photochemical quenching and quantum efficiency was observed under drought stress in strawberry cv. 'Elsanta', while non-photochemical quenching increased.

Inbreeding also caused changes in terms of vegetative and generative traits in strawberry plants. In this experiment, inbreeding depression resulted in si- gnificant reductions in fruit yield per plant (by 22.7\%), weight of single fruit (by 30.6\%), number of fruit per plant (by $47.6 \%$ ), and average weight of leaves per plant (by 67.1\%).

In domestic strawberries, fruit yield is among the traits that are most affected by inbreeding and can be reduced by as much as $80 \%$ after two generations of self-fertilization [12]. Similarly, Me lville et al. [27] reported that inbred lines showed smaller plant size, stems and leaves, fewer crowns as well as a decrease in yield. A study by $\mathrm{R} h$ o et al. [28] also showed a decline in plant height and leaf area, with 9-31\% decreases in the inbred lines in comparison with the original cultivars. In addition, fruit size and yield were reduced, whereas fruit quality was lower in terms of commercial value compared with the original cultivar.

Bellusci et al. [29] indicates that the magnitude of trait mean depression depends on the rate at which homozygosity accumulates and the strength of selection pressure counteracting this depression. Additionally, it is supposed that reciprocal recurrent selection would give more viable and homogeneous inbred lines.

The magnitude of mean depression observed for the inbred progeny in this study is consistent with the results obtained by Ż u r a w i c z [30], where a strong inbreeding cultivar, 'Dukat', caused a very strong reduction in yield compared to the families obtained through sib-crossing and mating of non-related parents.

In the opinion of $\mathrm{J}$ a $\mathrm{n}$ s e $\mathrm{n}$ et al. [31] as well as of $\mathrm{Michałek}$ and $\mathrm{Sawicka}$ [17], each cultivar produces assimilates in an individual way, as evidenced by different values of particular parameters of chlorophyll fluorescence obtained in the reported studies. Demming and Bjórkman [18], Michałek [32] as well as M i chałek and S aw i cka [33] also indicate that chlorophyll fluorescence is a measure of the efficiency of photosynthesis and that its effectiveness may depend on the characteristics of the genotype.

In conclusion, our results demonstrate that inbreeding in strawberry induces changes in photosynthetic parameters, yield and plant vigour.

\section{CONCLUSIONS}

1. The presented research shows that strawberry cultivars differ in their sensitivity to inbreeding as demonstrated by significant differences in photosynthetic efficiency, generative traits and vigour of plants.

2. Strong inbreeding caused a decrease in chlorophyll $a$ and $b$ content in all offspring.

3. The following characters: fruit yield per plant, weight of single fruit, number of fruit per plant and weight of leaves per plant, were lower in the $S_{3}$ generation as compared with parental forms. 


\section{Acknowledgments}

The presented research was funded by the Department of General Ecology, University of Life Sciences in Lublin.

\section{Authors' contributions}

The following declarations about authors' contributions to the research have been made: design of the experiments: WM, EK; performance of the experiments: WM, EK; analysis of the experimental data: EK, WM; writing of the paper: EK, WM.

\section{REFERENCES}

1. Bohlar - Nordenkampf HR, Lg SP, Baker NR, Öquist G, Schreiber U. Chlorophyll fluorescence as a probe of the photosynthetic competence of leaves in the field: a review of current instrumentation. Func. Ecol. 1989; 3: 497-514. http://dx.doi.org/10.2307/2389624

2. Guidi L, Nali C, Ciompi S, Lorenzini G, Soldatini GF. The use of chlorophyll fluorescence and leaf gas exchange as methods for studying the different responses to ozone of two bean cultivars. J. Exp. Bot. 1997; 48: 173-179. http://dx.doi.org/10.1093/jxb/48.1.173

3. He J, Huang LK, Chow WS, Whitecross MI, Anderson JM. Effects of supplementary ultraviolet-B radiation on rice and pea plants. Austr. J. Plant Physiol. 1993; 20:129-142. http://dx.doi.org/10.1071/PP9930129

4. Skór s k a E. Chlorophyll fluorescence of UV-B irradiated bean leaves subjected to chilling in light. Zesz. Probl. Post. Nauk Rol. 2002; 481: 391-394.

5. Baker N R, Rosenqvist E. Applications of chlorophyll fluorescence can improve crop production strategies: an examination of future possibilities. J. exp. Bot. 2004; 55: 1607-1621. http://dx.doi.org/10.1093/jxb/erh196

6. Razavi F, Pollet B, Steppe K, Van Labeke MC. Chlorophyll fluorescence as a tool for evaluation of drought stress in strawberry. Photosynthetica. 2008; 46: 631-633. http://dx.doi.org/10.1007/s11099-008-0108-7

7. Leszczyński B. Naturalna odporność roślin na szkodniki. /Natural resistance of plants to pests. [In:[ Biochemiczne oddziaływania środowiskowe. /Biochemical environmental effects. Eds. W. Oleszek, K. Głowniak, B. Leszczyński, AM Lublin, 2001; 87-108. (in Polish)

8. Gantner M, Michałek W. Measurements of chlorophyll fluorescence as an auxiliary method in estimating susceptibility of cultivated hazel (Corylus L.) for filber aphid (Myzocallis coryli Goetze). Acta Agrobotanica. 2010; 63: 189-195. http://dx.doi.org/10.5586/aa.2010.021

9. Falconer DS. Introduction to quantitative genetics. Second Edition. Longman Press, London. 1981.

10. Charlesworth D, Charlesworth B. Inbreeding depression and its evolutionary consequences. Annu. Rev. Ecol. Evol. 1987; 18: 237-268. http://dx.doi.org/10.1146/ annurev.ecolsys.18.1.237
11. Faedi W, Mourgues F, Rosati C. Strawberry breeding and varieties: situation and perspectives. Acta Hortic. 1999; 567: 51-60.

12. Shaw DV. Trait mean depression for second-generation inbred strawberry populations with and without parent selection. Theor. Appl. Genet. 1997; 95: 261-264. http://dx.doi. org/10.1007/s001220050557

13. Spangelo LPS, Hsu SS, Fejer SO, Watkins $\mathrm{R}$. Inbred line $\mathrm{x}$ tester analysis and the potential of inbreeding in strawberry breeding. Can. J. Genet. Cytol. 1971; 13: 460-469.

14. Genty B, Briantais J M, Baker NR. The relationship between the quantum yield of photosynthetic electron transport and quenching of chlorophyll fluorescence. Biochim. biophys. Acta. 1989; 990: 87-92. http://dx.doi.org/ 10.1016/S0304-4165(89)80016-9

15. Bohlar - Nordenkampf HR, Öquist G. Chlorophyll fluorescence as a tool in photosynthesis research. In: Photosynthesis and production in changing environment. Eds. D. O. Hall et all, Chapman and Hall, London. 1993; 193-206. http://dx.doi.org/10.1007/978-94-011-1566-7_12

16. Lichtenthaler HK, Wellburn A. Determination of total carotenoids and chlorophylls a and $\mathrm{b}$ of leaf extracts in different solvents. Biochem. Soc. Trans. 1983; 603: 591-592.

17. Michałek W, Sawi cka B. Zawartość chlorofilu i aktywność fotosyntetyczna średnio późnych odmian ziemniaka w warunkach pola uprawnego w środkowo-wschodniej Polsce. / Chlorophyll content and photosynthetic activity of medium-late potato cultivars in central-east Poland field conditions. Acta Agrophysica. 2005; 6: 183-195. (in Polish)

18. Demming B, Bjórkman O. Comparison of effect of excessive light on chlorophyll fluorescence and photon yield of $\mathrm{O}_{2}$ evolution in leaves of higher plants. Planta. 1987; 171: 171-184.

19. Maxwe11 K, Johns on GN. Chlorophyll fluorescence - a practical guide. J. Experimental Botany. 2000; 51: 659-668. http://dx.doi.org/10.1093/jexbot/51.345.659

20. Schreiber U, Bilger W, Hormann H, Neub a u e r C. Chlorophyll fluorescence as a diagnostic tool: basic and some aspect of practical relevance. [In:] A.S. Raghavendra (ed.), Photosynthesis a comprehensive treatise. Cambrige University Press. 2000; 24: 320-336.

21. Cichocka E, Goszczyński W, Chacińska M. The effect of aphids on host plants. [In:] Effect on photosynthesis, respiration and transpiration. Aphids and other homopterous insects. PAS. Warszawa. 1992; 3: 59-64.

22. Cichocka E, Goszczyński W. Biologia odżywiania i bezpośrednia szkodliwość mszyc. / Biology of nutrition and direct harmfulness of aphids. Zesz. Probl. Post. Nauk Roln. 1986; 329: 7-23. (in Polish)

23. Thomson VP, Cunningham SA, Ball MC, Nicotra AB. Compensation for herbivory by Cucumis sativus through increased photosynthetic capacity and efficiency. Oecologia. 2003; 134: 167-175.

24. Tomczyk A. Physiological and biochemical responses of plants to spider mite feeding. [In:] R.B. Halliday, D.E. 
Walter, H.C. Proctor, R.A. Norton, M.J. Colloff (eds), Proc. $10^{\text {th }}$ Int. Congr. Acarology. 2001; 306-313.

25. Sawicka B, Michałek W. Photosynthetic activity of Helianthus tuberosus L. depending on a soil and mineral fertilization. Polish J. of Soil Science. 2008; 41: 209-222.

26. Krebs D, Synkova H, Avatovščová N, Kočová M, S estak Z. Chlorophyll fluorescence measurements for genetic analysis of maize cultivars. Photosynthetica. 1996; 32: 595-608.

27. Melville AH, Galleta GJ, Draper AD, Ng TJ. Seed germination and early seedling vigor in inbred strawberry selections. HortScience. 1980;15:749-750.

28. Rho IR, Woo JG, Jeng HJ, Jeon HY, Lee C-H. Characteristics of $F_{1}$ hybrids and inbred lines in octoploid strawberry (Fragaria $x$ ananassa Duchesne). Plant Breeding. 2012; 131: 550-554.

29. Bellusci F. Pellegrino G, Musacchio A.Different levels of inbreeding depression between outcrossing and selfing Serapias species. Biologia Plantarum. 2009; 53: 175-178. http://dx.doi.org/10.1007/s10535-009-0029-8

30. Żurawicz E. Odziedziczalność najważniejszych cech użytkowych truskawki (Fragaria $x$ ananassa Duch.). Wyd. ISK Skierniewice. 1990. (in Polish)

31. Jansen LHJ, van Oevaren JC, van Hasselt PR, Kuiper PJC. Genotypic variation in chlorophyll fluorescence parameters, photosynthesis and growth of tomato grown at low temperature and low irradiance. Photosynthetica. 1995; 31: 301-314.

32. Mi ch a łek W. Fizjologiczne aspekty toksyczności monoi polimerycznej formy glinu na przykładzie sałaty (Lactuca sativa L.). / Physiological aspects of the toxicity of monoand polymeric forms of aluminum on the example of lettuce (Lactuca sativa L.). Wyd. AR Lublin. 2002. (in Polish)

33. Michałek W, Sawicka B. Chlorophyll fluorescence as physiological index of potato varieties. Conf. EAPR. 14-19.07.2002. Hamburg. 266.

\section{Zmiany we fluorescencji chlorofilu i cechach plonotwórczych u różnych genotypów truskawki (Fragaria $x$ ananassa Duch.)}

\section{Streszczenie}

Badania dotyczące aktywności fotosyntetycznej liści truskawki oparto na wynikach doświadczeń polowych przeprowadzonych w latach 2009-2010. Badaniami objęto 5 odmian: 'Kent', 'Teresa', 'Senga Sengana', 'Chandler' i klon hodowlany 1387 oraz uzyskane z nich potomstwo wsobne. Podczas doświadczenia określono zawartość chlorofilu a i b w świeżej masie liści oraz parametry fluorescencji: minimalną $\left(\mathrm{F}_{0}\right)$ i maksymalną $\left(\mathrm{F}_{\mathrm{m}}\right)$ fluorescencję, maksymalną sprawność fotosystemu PS II $\left(\mathrm{F}_{\mathrm{v}} / \mathrm{F}_{\mathrm{m}}\right)$, wskaźnik $\Delta \mathrm{F} / \mathrm{F}_{\mathrm{m}}$ ' określający całkowity zysk kwantowy fotosyntezy, minimalną $\left(\mathrm{F}_{0}{ }^{\prime}\right)$ i maksymalną $\left(\mathrm{F}_{\mathrm{m}}{ }^{\prime}\right)$ fluorescencję na świetle oraz współczynnik fotochemicznego (qP) i niefotochemicznego (qN) wygaszania fluorescencji. W pracy badano również wpływ chowu wsobnego na plon owoców i cechy plonotwórcze u truskawki. Z analizy danych wynika, że chów wsobny spowodował zmiany w wartościach powyższych parametrów u badanych odmian. U wszystkich potomstw wsobnych nastąpił spadek zawartości chlorofilu a i b w stosunku do odmian wyjściowych. Generalnie, silny chów wsobny nie zakłócał maksymalnej wydajności fotosystemu II $\left(\mathrm{F}_{\mathrm{v}} / \mathrm{F}_{\mathrm{m}}\right)$ oraz rzeczywistej wydajności fotochemicznej związanej z efektywnością transportu elektronów $\left(\Delta \mathrm{F} / \mathrm{F}_{\mathrm{m}}{ }^{\prime}\right)$. Uzyskane rezultaty wykazały również, że wartości parametrów qP i qN są uzależnione od reakcji poszczególnych genotypów na samozapylenie.

$\mathrm{W}$ pokoleniu $\mathrm{S}_{3}$ zaobserwowano spadek wartości następujących cech: plonu owoców z rośliny, liczby owoców z rośliny, średniej masy owocu i masy liści $\mathrm{z}$ rośliny w stosunku do form rodzicielskich.

Handling Editor: Elżbieta Weryszko-Chmielewska

This is an Open Access digital version of the article distributed under the terms of the Creative Commons Attribution 3.0 License (creativecommons.org/licenses/by/3.0/), which permits redistribution, commercial and non-commercial, provided that the article is properly cited.

CThe Author(s) 2013 Published by Polish Botanical Society 